\title{
Economic and image impacts of summer Olympic games in tourist destinations: a literature review
}

\section{Impactos econômicos e de imagem dos jogos Olímpicos de verão em destinos turísticos: uma revisão da literatura}

\author{
Luciana Brandão Ferreira \\ University of São Paulo, School of Economics, Business Administration and Accounting, 3900 Bandeirantes Avenue, 14040-905, Ribeirão Preto, \\ Brazil, bfluciana@gmail.com
}

Marina Toledo de Arruda Lourenção

University of São Paulo, School of Economics, Business Administration and Accounting, 3900 Bandeirantes Avenue, 14040-905, Ribeirão Preto, Brazil, malourencao@gmail.com

\begin{abstract}
Janaina de Moura Engracia Giraldi
University of São Paulo, School of Economics, Business Administration and Accounting, 3900 Bandeirantes Avenue, 14040-905, Ribeirão Preto, Brazil, jgiraldi@usp.br
\end{abstract}

Jorge Henrique Caldeira de Oliveira

University of São Paulo, School of Economics, Business Administration and Accounting, 3900 Bandeirantes Avenue, 14040-905, Ribeirão Preto, Brazil, jorgecaldeira@usp.br

\section{Abstract}

This article aims to verify in the literature related to the Summer Olympics the main economic and image implications for the destination hosting it. A qualitative exploratory research was carried out with the survey of scientific articles of the last twenty-five years in five different databases. The studies indicate economic and image gains and losses from hosting the games. As positive aspects, most of the studies mention those coming from Olympic spending that provided long-term gains for the resident population in the host locality and related to tourist activity. The most cited negative aspects are related to investments that generated benefits only in the short term or lack of investment in infrastructure. It is concluded that the preparation and implementation processes in each country are too different for the results to be uniform. In addition, the diverse methodological aspects of the articles also influence their results.

Keywords: Summer Olympic Games, economic impacts, tourist destination image.

\section{Resumo}

Este artigo tem por objetivo verificar na literatura relacionada aos Jogos Olímpicos de Verão as principais implicações econômicas e de imagem para o destino que o hospeda. Realizou-se uma pesquisa exploratória qualitativa com levantamento de artigos científicos dos últimos vinte e cinco anos em cinco bases de dados diferentes. Os estudos encontrados indicam ganhos econômicos e de imagem, bem como perdas ao se realizar um megaevento esportivo. Como aspectos positivos, a maioria dos estudos menciona aqueles provenientes de investimentos olímpicos que proporcionaram ganhos a longo prazo para a população residente na localidade de acolhimento e relacionados com a atividade turística. Os aspectos negativos mais citados estão relacionados a investimentos que geraram benefícios apenas no curto prazo, ou falta de investimento em infraestrutura. Conclui-se que os processos de preparação e implementação em cada país são muito diferentes para que os resultados sejam uniformes. Além disso, os diversos aspectos metodológicos dos artigos também influenciam seus resultados.

Palavras-chave: Jogos Olímpicos de Verão, impactos econômicos, imagem de destino turístico.

\section{Introduction}

Studies on the impact of international mega-events in the host countries have been carried out, especially with regard to mega-sport events (Chen, 2012). The hosting of these events, by virtue of their size, bring changes to the country, either in more tangible aspects such as investments in infrastructure and works, or intangible aspects such as political and social climate, and image. In addition to issues related to infrastructure and economic development, a point cited in scientific articles on the subject is the image as a tourist destination of the site that hosts the mega-event (Knott, Fyall, \& Jones, 2015; Deng \& Li, 2013). There is a strategic leverage of images that are shown to the world in conjunction with the event (pre, during and after), and the level of awareness of a given city and/or country can be raised, which can boost tourist visitation at some point in the future, or at least be used to educate the world about a specific locality (Gibson, Qi \& Zhang, 2008).

The objective of this article is to verify what are the main economic and destination image implications for the host city of a sports mega-event that have been described in the literature. For the survey, the Summer Olympic Games were chosen as they are considered the biggest sporting event in the world, including a series of sports, have a high media impact, and require a great investment. A qualitative exploratory research was carried out by means of mapping and analysis of articles in five databases that dealt with economic and image aspects for the host of the Summer Olympic Games of the last 25 years.

Mega-events are usually evaluated in terms of the economic impact of the event itself, with little focus given to the event as part of the larger process that can be investigated longitudinally (Hiller, 2006). Müller and Moesch (2010) argue that substantial economic effects can be expected from mega-events, especially with respect to tourism. Regarding the image, Getz (1993) emphasizes that mega-events generate much of the tourist demand and contribute to creating a positive image of the destination. A positive image of the destination may influence the intention to visit it as studies have indicated (Pike \& Ryan, 2004), which will in some way generate economic impact. 
This study is relevant because it brings together the literature on Olympic Games of the last decades, becoming a facilitator for future studies on this theme, and also for the chosen approach. The aim is to show both sides of the achievement of a sport mega-event, since one of the divergent points of this literature are studies that argue that the benefits of the megasporting events justify the high investments (Chen, 2012) while others indicate that the investments are very high in comparison to the positive results, be they economic or image (Melo, 2014).

\section{Method}

This study has an exploratory nature and is based on a systematic literature review on academic studies that approached the themes: economic aspects of Olympic Games and/or image of the destination (Table 1).

\section{Table 1. Search filters}

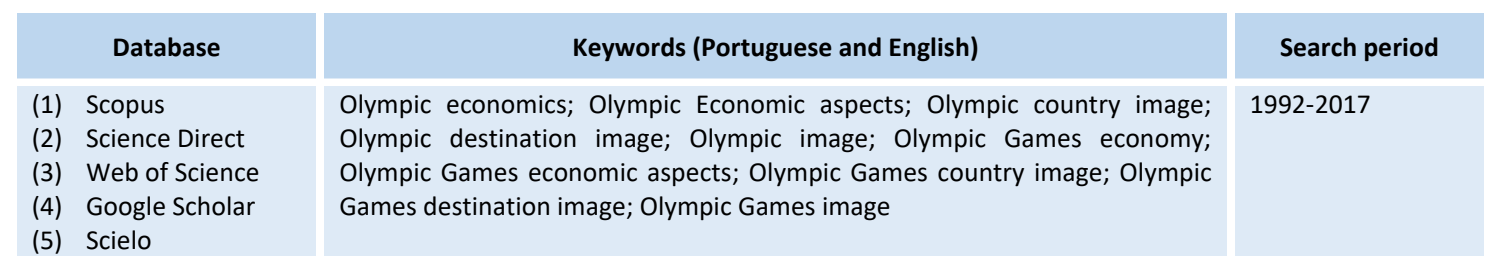

Source: Own elaboration.

A selection of the studies found was made with the objective of framing them in the same scope. The criteria used to select the articles to be analyzed in the present study were: (a) the studies should address economic and/or destination image impacts for the host country/city of the event; (b) should only deal with Summer Olympic Games that have already occurred, and cannot report prediction for future games in both economic and image attributes. For this work, studies of seven summer Olympic Games were analyzed (Table 2).

Table 2 - Summer Olympic Games

\begin{tabular}{|c|c|}
\hline Year & Event \\
\hline 2016 & Rio de Janeiro Olympics \\
\hline 2012 & London Olympics \\
\hline 2008 & Beijing Olympics \\
\hline 2004 & Athens Olympics \\
\hline 2000 & Sydney Olympics \\
\hline 1996 & Atlanta Olympics \\
\hline 1992 & Barcelona Olympics \\
\hline
\end{tabular}

\begin{tabular}{|c|c|c|c|}
\hline Title & Authors & Objective & Results \\
\hline 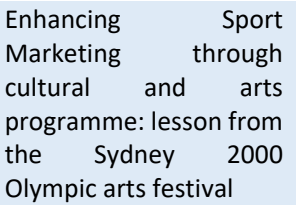 & Garcia (2001) & $\begin{array}{l}\text { Discuss potential to broaden } \\
\text { marketing appeal of sporting } \\
\text { events by associating them with } \\
\text { cultural and artistic activities at } \\
\text { the Sydney Olympics. }\end{array}$ & $\begin{array}{l}\text { The limit of success for joining sports and } \\
\text { promoting cultural events is mainly due to } \\
\text { the lack of integration mechanisms between } \\
\text { them. }\end{array}$ \\
\hline $\begin{array}{l}\text { Economic Aspects and } \\
\text { the Summer } \\
\text { Olympics: a Review of } \\
\text { Related Research }\end{array}$ & Kasimati (2003) & $\begin{array}{l}\text { Analyze methods used in } \\
\text { economic studies on Summer } \\
\text { Olympics and compare models } \\
\text { and forecasts from economic } \\
\text { studies on Olympics of ex-ante } \\
\text { and ex-post approaches. }\end{array}$ & $\begin{array}{l}\text { Thirteen studies investigate economic } \\
\text { variables related to the games, which have } \\
\text { been classified as ex-ante and ex-post } \\
\text { economic impact assessments. Ex-ante } \\
\text { models and forecasts have not been } \\
\text { confirmed by ex-post analysis and this leads } \\
\text { to the need for a better theory. }\end{array}$ \\
\hline $\begin{array}{l}\text { Impact of the Olympic } \\
\text { games as mega-events }\end{array}$ & $\begin{array}{l}\text { Malfas, } \\
\text { Theodoraki } \\
\text { and Houlihan } \\
\text { (2004) }\end{array}$ & $\begin{array}{l}\text { Review the literature on mega- } \\
\text { event features and show } \\
\text { particular examples of recent } \\
\text { Olympic Games. }\end{array}$ & $\begin{array}{l}\text { The legacies that follow the hosting of the } \\
\text { games in the countries are difficult to } \\
\text { quantify, is inclined to multifaceted political } \\
\text { interpretations. }\end{array}$ \\
\hline
\end{tabular}

Table 3 indicates the number of articles that fit the scope of the research. From a total of 92 articles initially found, 57 addressed: economic aspects, image aspects, or both, and considered the period after the Olympic Games.

Table 3 - Selected articles

\begin{tabular}{|c|c|c|c|}
\hline Image & Economic & $\begin{array}{c}\text { Other aspects } \\
\text { including image } \\
\text { and economic } \\
\text { aspects }\end{array}$ & $\begin{array}{c}\text { Total number } \\
\text { of articles } \\
\text { within the } \\
\text { scope }\end{array}$ \\
\hline 20 & 15 & 22 & 57 \\
\hline
\end{tabular}

Source: Own elaboration.

\section{Results and discussion}

Table 4 shows a summary of the major articles in increasing chronological order. 


\begin{tabular}{|c|}
\hline Title \\
\hline $\begin{array}{l}\text { Event business } \\
\text { leveraging The Sydney } \\
2000 \text { Olympic Games }\end{array}$ \\
\hline $\begin{array}{l}\text { Who were the winners } \\
\text { and losers of the } \\
\text { Olympic Games? }\end{array}$ \\
\hline $\begin{array}{lr}\text { Understanding } & \text { strategic } \\
\text { alignment } & \text { for } \\
\text { destination marketing } \\
\text { and the 2004 } & \text { Athens } \\
\text { Olympic } & \text { Games: } \\
\text { Implications } & \text { from } \\
\text { extracted } & \\
\text { tacit knowledge } & \end{array}$ \\
\hline $\begin{array}{l}\text { Olympic } \quad \text { Games } \\
\text { reinvention: a marketing } \\
\text { project }\end{array}$ \\
\hline
\end{tabular}

Assessing the impact of the 2004 Olympic Games on the Greek economy: a small macroeconometric model

Economic reading of the Olympic Games: financing, organization and results

Perceptions of Risk and Travel

Intentions: The Case of China and the

Beijing Olympic Games

Relationships among
behavioural intentions,
cognitive event and
destination images
among geographic
different olympic
regions of Olator
Games spectator

Estimating Olympicrelated Investment and Expenditure

Thoughts on the real macroeconomic effects of Beijing 2008 Olympics on the Chinese economy

China and the Olympics: views of insiders and outsiders

\section{Authors \\ Objective}

'Brien (2005)

O'Brien (2005)

Tavares (2005)

Singh and $\mathrm{Hu}$ (2008)

Proni (2008)

Kasimati and

Dawson

(2008)

Proni, Araujo and Amorim (2008)

Qi, Gibson \& Zhang (2009)

Kaplanidou (2009)

$\mathrm{Li}$ and Blake

(2009)

Yao, Maseri and Rasli

(2010)

Heslop, Nadeau and O'Reilly (2010)
Analyze the development and implementation of the business club for business networking, an initiative of the Australian Government to create leverage for the Olympic Games.

Investigate how the interests and effects added to the games can generate social, political and economic gains and losses through a literature review.

To extract the knowledge of the two major organizations involved in the 2004 Olympics to uncover problems about the strategic alignment between Olympic and marketing plans and propose a model for future host countries,

To examine the transformation of the modern Olympics in the last decades, from an economic perspective.

Examine the impact of the 2004 Olympics on the Greek economy.

Disseminate results of studies developed by IPEA on the Olympic Games

Examine the relationship between risk perception and intention to travel to the Beijing Olympics.

To examine the cognitive impact of the event on spectators according to their geographic region an assess their intentions of revisiting the destination.

To build models to indicate the origin of Olympic-related investments and their costs, the model is applied to the Beijing 2008 Olympic Games

Briefly analyze the macroeconomic effects of the Beijing Olympics on the Chinese economy.

Examine the vision of the residents and foreigners of the Olympics and the country of origin before and after the megaevent.

\section{Results}

The leverage of business events represents a subtle, though significant, a paradigm shift in international events.

An Olympic bid must assess the risk of possible negative effects since the games can have a lower socio-political-economic balance than imagined and increase polarization and social inequality.

For success in destination marketing, strategies involving two domains (Olympic plan and tourist destination) must be coordinated and carefully aligned.

The adoption of a business logic has corrupted the Olympic ideology emerged in a sociocultural context, such an ideology has no more adherence in contemporary society.

Even if costs are high during the year and game preparation, the legacy effects of the long-term economy appear to be rather modest.

Targeting a huge amount of resources to one city can mean depriving many others and fueling regional inequalities. It should be noted that there are other types of government investment that can also increase GDP and create jobs.

A factor analysis revealed four perceived risk factors: personal security, cultural risk, sociopsychological risk and risk related to violence. Using regression analysis revealed that violence related risk and sociopsychological risk had a negative impact on participants' intention to visit China as tourists.

Differences were found between Europeans and Americans in the images of destinations related to the place of attraction and among Asian, European and American people related to the image of the infrastructure of the Olympic event and its organization. They did not differ in their intentions of revisiting the host country. Past experience with the destination was a significant influence on intentions.

The model is suitable for checking how much was spent on the Olympic Games and may have application for other mega-events.

Based on authoritative statistics, this study concludes that the effects continue to transform the Chinese economy in transportation, banking, insurance and travel consumption in the long-term.

Although the prior image is successful, postevent evaluations are much lower. 


Title
Images of power:
architectures of the
integrated spectacle of
the Beijing Olympics
Beijing 2008: the
Olympic Games, the city
and the spaces
The Economic Benefits
of Mega Events: A Myth
or a Reality? A
Longitudinal Study
at the Olympic Games
Modelling the economic
impact of international
tourism on the Chinese
economy: a CGE analysis
of the Beijing 2008
Olympics

The Impact of International TV Media Coverage of the Beijing Olympics 2008 on China's Media Image Formation: A Media Content Analysis Perspective

An Olympic legacy for all? The noninfrastructural outcomes of the Olympic games for socially excluded groups (Atlanta 1996 - Beijing 2008)

Towards Reviving PostOlympic Athens as a Cultural Destination

The Olympic games and the improvement of economic well-being

Country branding through

Olympic Games

Modelling the economic impact of sports events: The case of the Beijing Olympics

London 2012 and Rio de Janeiro 2016:

Concept and Reality in the Production of the Olympic City

\begin{tabular}{|c|c|}
\hline Authors & Objective \\
\hline $\begin{array}{c}\text { Broudehoux } \\
\text { (2011) }\end{array}$ & $\begin{array}{l}\text { Examine the role of spectacular } \\
\text { architecture in Beijing's } \\
\text { redevelopment amid } \\
\text { preparations to host the } 2008 \\
\text { Olympics. }\end{array}$ \\
\hline
\end{tabular}

Analyze the organization and

Tavares relationship of the Beijing venues

(2011) and the 2008 Olympic Games. of the Olympics on the host countries was significant.

\section{(2011)}

Take a first step in the application of computable general equilibrium (CGE) modelling to

Li, Blake and Cooper (2011) predict the economic contribution of tourism generated by the Beijing Olympic Games international TV in covering the 2008 Beijing Olympics

Zeng, Go and

Kolmer (2011)

Minnaert

Boukas, Ziakas and Boustras

Chong and Hui

(2012)

Sun and Paswan (2012)

Li, Blake and

Thomas

(2013)

Mascarenhas

(2013)

Identify planning principles that allow the development of noninfrastructure benefits for socially excluded groups in the cities where the Olympics were held

Identify how global changes have affected Athens, its tourism and its competitiveness after the Olympics.

Investigate whether to host the Olympic Games can improve the economy of host countries.

Investigate whether hosting a major international event impacts the host country's brand image among individuals living outside of the host

country and whether there was any effect on intention to purchase products from the host country by non-residents.

Contrast the approaches used in the classification of economic impact at the Beijing Olympics by means of a literature review.

Discuss the "Barcelona model" that influenced the bids of London and Rio de Janeiro.
Explain the impact of

$\begin{array}{ll} & \text { Results } \\ \text { Architectural mega-projects have }\end{array}$

contributed to legitimizing autocratic power structures in post-socialist China, serving as an imagery and state propaganda tool and diverting attention from social ills caused by the process of redevelopment.

The games acquire spatial attributes that transcend the city's identity and its interaction character seems to be related to the political project of the host country.

The results indicate a significant impact on the economic impact of Olympic Games in host countries only in terms of certain parameters (e.g. GDP and unemployment in the pre-games stage) in the short term.

Positive international economic impacts of international tourism were foreseen in the ex-ante analysis, but the impact was analyzed as negative in the ex-post version.

It cannot be concluded that the Beijing Olympic Games directly influenced the image of China. Indirectly, however, the international media took an interest in the host country and thus helped to make the country's image clearer.
The Olympics usually bring few benefits to low-income social groups although they are often justifications for the bidding stage. A similar emphasis is proposed between environmental sustainability and social sustainability.

Changes affecting Athens: socio-cultural and economic changes; of identity and image. Improvements in the tourism sector: infrastructure, quality of services and new markets.

The economies of host countries improve after the announcement that they will host the games. The improvement peaks in the game year and remains significant for 8 years after.

Hosting the Olympic Games had direct and indirect effects on purchase intention due to the change in the country brand image.

The Olympics in Beijing have benefited the country economically, but the impact is not significant for the total economy. The impact on tourism is greater.

The London project was focused on urban regeneration of an old industrial area. The Rio de Janeiro Olympic project closely resembles that of Beijing 2008: high budget, large-scale violent evictions. 


\begin{tabular}{|c|c|}
\hline Title & Authors \\
\hline $\begin{array}{l}\text { Mega-events and urban } \\
\text { and regional } \\
\text { development: an } \\
\text { analysis of specificities } \\
\text { and impacts from the } \\
\text { Olympic Games and a } \\
\text { panorama of the city of } \\
\text { Rio de Janeiro. }\end{array}$ & $\begin{array}{l}\text { Pires, Baptista } \\
\text { and } \\
\text { Portugal } \\
\text { (2013) }\end{array}$ \\
\hline $\begin{array}{l}\text { The structural legacies of } \\
\text { the Olympic Games } \\
\text { (1992-2008): a literature } \\
\text { revision }\end{array}$ & $\begin{array}{l}\text { Pampuch } \\
\text { Almeida \& } \\
\text { Marchi Júnior } \\
\text { (2014) }\end{array}$ \\
\hline $\begin{array}{l}\text { The London } 2012 \\
\text { cultural programme: A } \\
\text { consideration of } \\
\text { Olympic impacts and } \\
\text { legacies for small } \\
\text { creative organizations in } \\
\text { east London }\end{array}$ & $\begin{array}{c}\text { Pappalepor, } \\
\text { Duignan (2015) }\end{array}$ \\
\hline $\begin{array}{l}\text { Transformation of } \\
\text { Tourism in Beijing after } \\
\text { the } 2008 \text { Summer } \\
\text { Olympics: An Analysis of } \\
\text { the Impacts in } 2014\end{array}$ & $\begin{array}{c}\text { Singh and Zhou } \\
\text { (2015) }\end{array}$ \\
\hline $\begin{array}{l}\text { A Strategic Approach for } \\
\text { Export: Improving } \\
\text { Country Image } \\
\text { Through the Olympics }\end{array}$ & $\begin{array}{l}\text { Demir, Elioz, } \\
\text { Cebi and } \\
\text { Yamak (2015) }\end{array}$ \\
\hline $\begin{array}{l}\text { Influence of event image } \\
\text { on destination image: } \\
\text { The case of } 2008 \\
\text { Beijing Olympic Games }\end{array}$ & Lai (2016) \\
\hline $\begin{array}{l}\text { Revisiting the host city: } \\
\text { An empirical } \\
\text { examination of sports } \\
\text { involvement, place } \\
\text { attachment, event } \\
\text { satisfaction and } \\
\text { spectator } \\
\text { intentions at the London } \\
\text { Olympics }\end{array}$ & $\begin{array}{c}\text { Brown, Smith } \\
\text { and Assaker } \\
\text { (2016) }\end{array}$ \\
\hline $\begin{array}{l}\text { Mega-events and the } \\
\text { transformation of Rio de } \\
\text { Janeiro into a } \\
\text { Mass transit city }\end{array}$ & $\begin{array}{c}\text { Lindau, } \\
\text { Petzhold, } \\
\text { Tavares and } \\
\text { Facchini (2016) }\end{array}$ \\
\hline $\begin{array}{l}\text { Attitudes toward } \\
\text { attending the } 2016 \\
\text { Olympic Games and } \\
\text { visiting Brazil } \\
\text { After the games }\end{array}$ & $\begin{array}{l}\text { Rocha and Fink } \\
\text { (2017) }\end{array}$ \\
\hline
\end{tabular}

\section{To analyze the impacts of mega-} events, especially the Olympics, and to outline the possibilities and expectations for their accomplishment in the city of Rio de Janeiro.

Literature review to identify the impact of investments in 19922008 host cities

Investigate the impact of the 2012 London Olympics and its cultural programme on the sites of small tourist organizations in East London.

Understand how the Beijing Olympics influenced the local tourism sector.

Measure the effects of the Olympic Games on the national brand by analyzing the host export figures of the Olympic Games after 2000.

Provide a better understanding of the influence that an event image (EI) has a destination image (DI)

Assess whether involvement with sports and attachment to the venue influence the intent to search the country and satisfaction with the event.

Describe the benefits obtained after the implementation of BRT in Rio de Janeiro.

Describe the impacts of the interaction between the Olympic and Brazilian brand images (as a tourist destination) and the attitudes to participate in the Rio 2016 Olympic Games and to visit the country after the event.

\section{Results}

Transport systems are essential for megaevents. It is important to devise travel demand management strategies to reduce road vehicles, as well as the constant management of possible traffic problems.

The literature shows the difference in results on subsequent benefits of the structures in the several cities that have hosted megaevents, both in terms of location and costs of access.

The gap between the Olympics and local reality. Problems include inadequate site consultation, barriers to access opportunities, and the inability of effective levelling.

Beijing developed because of the Olympics; the department of tourism, hotels and restaurants have changed their marketing strategies.

The effects on the national brand are not very clear in terms of exports. Only improving the national brand is not enough to increase exports in the countries.

Generally, EI is positively related to DI and this correlation varies in intensity according to the different levels and dimensions of the two imaging constructs.

The involvement of the sport and the attachment to the place influenced the intentions of revisiting the country but did not influence the satisfaction of the event.

Travel time benefits were obtained and there were gains in user satisfaction after BRT.

The interaction between the hospitality associated with the hospitality of the Olympic Games and that of Brazil positively affected the attitudes towards the visit to the country after the Games. The association with the Olympic brand may bring fewer gains to Brazilian tourism than expected.

\section{Source: Own elaboration}

On positive/negative points of hosting the games, the specifics of each country are highlighted for the result of the impacts. Some points are recurrent such as the economic impact on tourist activity, impacts on strategic areas such as transportation and urban infrastructure, the large sums invested and questions about the possibilities of greater gains if investments were made in areas other than the event, the opportunity cost. Based on the review, an account was made of the main economic/image impacts highlighted in the literature, considering the chronological order of the events.

\subsection{Barcelona Olympic Games}

On the economic aspects related to the 1992 Olympic Games, the investments for the permanent use of the population generated positive revenues, with positive economic impacts for Barcelona (Proni, 2008; Casellas, Jutgla \& Pallares-Barbera, 
2010). The main feature of the organization of the event was the high proportion of its own income formed with the contribution of sponsors.

The main programs developed were facilities; services to the Olympic family; telecommunications/electronics; competitions; commercial management; ceremonies/cultural acts; image and security. Civil projects received $61.5 \%$ of investments and construction $38.5 \%$ (Proni, Araujo, Amorim, 2008). It is understood that the most important effects of the 1992 Barcelona projects would be guaranteed over the long term. The main structural projects were the construction of the ring road; a key road to traverse the whole circumference of the city; the opening to the sea, with the construction of the Olympic village; and the creation of several new centers and Olympic zones in Montjuïc, Diagonal and Vall de Hebron (Proni et al., 2008). In addition, a large part of the investment was made in new transport systems and in the rejuvenation of the country's coast, and a new marina was built on the site (Malfas, Theodoraki, Houlihan, 2004).

Malfas et al. (2004) also stated that from October 1986 to July 1992 the unemployment rate dropped from $18.4 \%$ to $9.6 \%$, due to the fact that it was necessary to hire a larger number of employees to perform the works related to the preparation of the games. Because of this, the authors emphasize that only a part of the work generated was permanent. The Olympic Games in Barcelona were characterized by geographical decentralization: they were distributed through a series of cities called Olympic sub-hosts (Proni et al., 2008). Only $38.5 \%$ of the Olympic investments were made in Barcelona, while $61.5 \%$ of the projects were carried out outside the metropolitan area, in the rest of Catalonia or were not limited to a certain location, such as investments in the telecommunications sector.

In relation to the image, the Olympic Games that took place in Spain had a positive legacy not only on the part of structural investments for the country but also in obtaining a positive image of it, that could be disseminated throughout the world, strengthening the destination towards other countries and bringing legacies from these transformations to the population (Pampuch, Almeida, Marchi Júnior, 2014).

\subsection{Atlanta Olympic Games}

According to Malfas et al. (2004), a 2-billion-dollar investment was made in Olympic-related projects between 1990-1996. As a result, more than 580,000 new jobs were created in the region between 1991-1997 and the economic impact of these games on those 6 years was 5.1 billion dollars. Hotchkiss, Morre and Zobay (2003) also highlight the increase in employment but emphasize that there was no increase in wages.

However, many investments were only on paper, the transport system did not perform well, neither did the TI system of the games that had several flaws (Proni, 2008). The investment in security was not enough and the relationship of the population with the visitors was inadequate. Despite this, the games stood out for the good transmission and retransmission of the images and the innovation in relation to the measurement of the results of the competitions. In addition, IBM, a global computer maker, made available technologies to provide the media with real-time information and statistics (Proni, 2008).

Atlanta games did not achieve the non-infrastructure for the population of low income such as the incentive for sport, development of volunteer works, training and educational actions, and a sufficient increase in the number of jobs (Minnaert, 2012). The Atlanta games serve as a telling case of the negative social impacts of a mega-event, 15,000 residents were evicted from public housing projects that were demolished to build Olympic lodgings. In addition, 350 million dollars in public funds failed to be invested in low-income housing, social services, and other support services for homeless and low-income citizens and instead was used in Olympic preparations (Malfas et al., 2004).

Many shelters were converted into lodgings during the games. Financial incentives were offered to social service organizations to convert their facilities into tourist accommodation for two weeks instead of accommodating low-income people. Finally, the Olympic Games in 1996 were financed by private enterprise, with an investment of 1.6 billion, but costs exceeded the forecasts for the games by 2 billion (Proni, 2008).

Regarding the image formed of the USA and Atlanta, no studies were found that reported image gains. However, Proni (2008) reports some negative aspects that contributed to the dissemination of a negative image of the games to the population and to question the readiness of Atlanta to receive the games. The main aspects responsible for this negative image were: safety, athletes' reception and transportation failures (Proni, 2008). In addition, the tourism in the city was not as expected (Pampuch et al. 2014).

\subsection{Sydney Olympic Games}

About the economic aspects, 6.5 billion dollars were spent on these Olympics, with more than 3 billion invested in infrastructure and sports facilities (Proni, 2008). The author emphasizes that there have been improvements in pollution control services, the creation of new roads and rail links, improvement in telecommunication, and the electricity service.

The 2000 Olympics organization developed infrastructurerelated goals for the local low-income population, focusing on social sustainability. The homeless policy is an example of a lasting result obtained with the games (Minnaert, 2012). For the encouragement of foreign trade tied to the country, during the games, the business club was developed, organized by the federal government of Australia. This event was intended to encourage marketing and leverage relationship networks between Australian and international entrepreneurs (O'Brien, 2005).

For the first time in the history of the Olympic Games, the environment was placed as a priority. Actions such as 
decontamination of Homebush Bay, placing it as the centre of the Olympic Games; implementation of techniques for reuse of water, energy, waste and concern for sustainable development conveyed the idea that the world needed (Proni et al., 2008). For the authors, the main expenses were sequential: technology; Sydney Olympic radio broadcasting organization; Olympic village; safety; workers; ceremonies and ticket sales. These games still had good repercussions for the local population; the expenses realized were considered valid and legitimate by the majority of the inhabitants (Proni, 2008). There was a strong impact on the local economy. Between 1997 and 2000 GDP was higher by 1.4 billion than it would have been if it had not hosted the games (Proni, 2008).

However, the policy related to the increase in jobs, for example, was not sufficiently explored. The total revenue of the Olympics did not exceed the costs (Proni, 2008). Concerning the image of the country and the city, Australia's country brand became more popular, and during the years prior to the event, Sydney was classified by the main international publications as one of the cities favoured for the visitation of tourists and executives (Proni, 2008).

Garcia (2001) emphasizes the concern of the image that the country would present to foreigners. Due to this concern, four Olympic art festivals were held from September 1997 to October 2000, each responsible for covering a different aspect of the country's cultural identity. The festivals were multicultural with focus also on the Aboriginal heritage to arouse curiosity towards the Australian way of life and its culture.

\subsection{Athens Olympic Games}

The Olympics had a positive impact on the Greek economy. In the period from 1997 to 2005, the games leveraged economic activity at around $1.3 \%$ of GDP per year, while unemployment fell by around $1.9 \%$ per year. For the period from 2006 to 2012, the effect of the games was more modest with GDP increasing by 0.46 and $0.52 \%$ per year and unemployment falling by 0.17 \% per year (Kasimati \& Dawson 2008). Boukas et al. (2012) highlight improvements in the tourism sector after the megaevent. According to Malfas et al. (2004) 1.4 billion pounds was spent on the opening of new airports. In addition, 820 million pounds were used to expand the city's subway, which was completed in 2001, in addition, the works of the games allowed the creation of 30,000 jobs (Malfas et al., 2004).

Among the negative aspects to be pointed out are the loss of about 1.5 billion dollars. As a way of trying to control the exacerbated spending, the Greek government announced an audit on the accounts of the organizing committee after the game's closure. The need to carry out the audit was justified because of reports of over-invoicing and misuse of public resources (Proni, 2008). There were delays in the works, traffic jams and blocking of roads, which triggered the production of a negative image. Large expenditures were made in attempting to meet deadlines and also abandoning facilities built for competitions (Chong \& Hui, 2012).

The delay in planning and construction in Athens, in addition to providing bad publicity, was also responsible for questioning by many about the completion of the works and whether the city would be able to prepare on time for the event. The image of the city and the host country also came into question (Chong \& Hui, 2012). The authors report that there were three main areas of concern regarding the negative publicity received by Greece during the preparation of the Olympic Games: the slow progress of the works, the non-effective security, and the high price charged for tourists to stay. Various problems of negative publicity could have been avoided if there had been more careful coordination between the Greek national tourism organization and the Athens organizing committee (Chong \& Hui, 2012).

\subsection{Beijing Olympic Games}

Broudehoux (2011) discusses the exuberance in constructions made in Beijing to host the Olympics, Beijing has been redeveloped. The great investment in works had the purpose of projecting the image of a successful economy to foreigners. The event was the most expensive of all time (Proni et al., 2008). The preparation required investments of US\$34 billion in infrastructure to transform the city and its region. The event brought a number of economic benefits and boosted environmental preservation, confirming the legacy that the Olympic Games have left in their previous staging.

The authors argue that it is likely that the event had a positive influence on Chinese economic development, especially in sectors such as media, television, Internet, mobile phones, "clean" energy and sports equipment. Excitement for the Olympics brought many sectors into a kind of "international revolution". However, the decisive aspect for the Chinese government does not seem to be the economic impact of the Games, but the demonstration of what China is capable of offering the world.

In addition to airports, new transport systems were built, US\$ 40 billion in environmental protection, railways, highways, stadiums and airports were invested in three host cities, Beijing, Shanghai and Qingdao (Chong \& Hui, 2012). Receiving the Olympics in Beijing benefited the local population, but these benefits were not significant for the total economy (Li et al., 2013). According to the authors, the larger the economy of the country or city that will host the Olympic Games, the lower the economic impact of hosting the event. In an ex-ante and ex-post study, Li et al. (2011) also found that in terms of tourism, forecasts were more optimistic than the results.

Despite contributions to the city's infrastructure, about 1.5 million residents were displaced to carry out the works (Tavares, 2011). The redevelopment spectacle, with new architectural constructions designed to obtain an Olympic image of the new Beijing, has managed to divert attention from 
the growing contradictions in Chinese society (Broudehoux, 2011).

On the image that foreigners have of China, Qi, Gibson and Zhang (2009) indicate that American students view China as a country of moderate risk in relation to personal security, violence, cultural risks and socio-psychological risks. For them, during the Olympic Games, it was less risky to visit the country than at any other time.

\subsection{London Olympic Games}

This one has few studies, perhaps because it is one of the most recent Olympics. Mascarenhas (2013) reports that the London Olympics sought to modernize and improve the infrastructure of a more degraded area of the city. According to the author, the Olympic Games benefited the city with the improvement in transportation in these areas and having a difference in relation to the other Olympics whereby the number of expropriations carried out was small. Brown, et al. (2016) emphasized the positive intention of revisiting the destination after the games, which implies future economic impacts.

There were also negative points such as the rise in prices in the city and greater peripheralization of the poor (Mascarenhas, 2013). The Olympic cultural programme failed to benefit the small arts organizations because the program goal was not aligned and communicated to the participating artists (Pappalepore \& Duignan, 2015). It is noted that the studies found on the London Olympics, unlike the others, did not raise numbers related to the possible economic development coming from the preparation and accomplishment of the event. Nor were there studies that addressed differences in the image of the tourist destination due to the mega-event.

\subsection{Rio de Janeiro Olympic Games}

The Summer Olympics in Brazil happened in 2016 and it was the most recent edition of the event. Only two articles were found that fit with the filters established for this study: Lindau et al. (2016), Rocha and Fink (2017). The first one focuses more on economic and social aspects since it is related to the transportation investments and transformation that happened in Rio de Janeiro city to be prepared for the Olympic Games. The investments in transit supply began years before the mega-event. The strategy included implementation of an integrated high capacity and performance bus-based transit network fully integrated to the existing boat and heavy rail systems - BRT (Lindau et al., 2016). According to the authors, Rio de Janeiro's BRT network provides social and infrastructure legacy for the city, offering not only employment opportunities, but recreation and leisure as well. The mass transit increased from $18 \%$ to $63 \%$, benefiting almost 1.5 million passengers per day.

Regarding destination image, Rocha and Fink (2017) described the impacts of the interaction between, the brand images of The Olympic Games and Brazil, to the attitudes toward attending the 2016 Rio Olympic Games and visiting the country after the event. The results showed that the interaction between the hospitality associated with the Olympic Games and that of Brazil positively affected attitudes toward visiting the country after the Games. However, in the qualitative part of the study using focus groups with sports management graduate students, they concluded that the association with the Olympic brand might bring fewer gains to Brazilian tourism than expected. One important thing highlighted in this article was the context of the Olympic Games hosted by developing countries. In this situation, the authors defend that the country brand image should benefit more from the association with the event than the opposite.

\section{Main findings in the literature}

A survey of the main findings from the published literature highlights the large number of publications in the 2000s, especially since 2008 , which coincides with the Beijing Olympics in China. It is also observed that among the articles dealing with some specific staging of the Olympic Games, China was the country with the largest number of studies. (Figures 1 and 2). This fact raises some explanatory hypotheses, such as few emerging countries among those that hosted this mega-event in recent staging; it is a country with a social and economic profile different from the others; it still has a relatively closed economy; at the same time it stands out as a strong and growing economy and a large consumer market, generating greater global visibility; finally, it has strong social contradictions, which are also pointed out as negative aspects raised in the articles about destination image (Li \& Kaplanidou, 2013; Heslop et al., 2010).

Figure 1 - Economic/Image Papers per Year

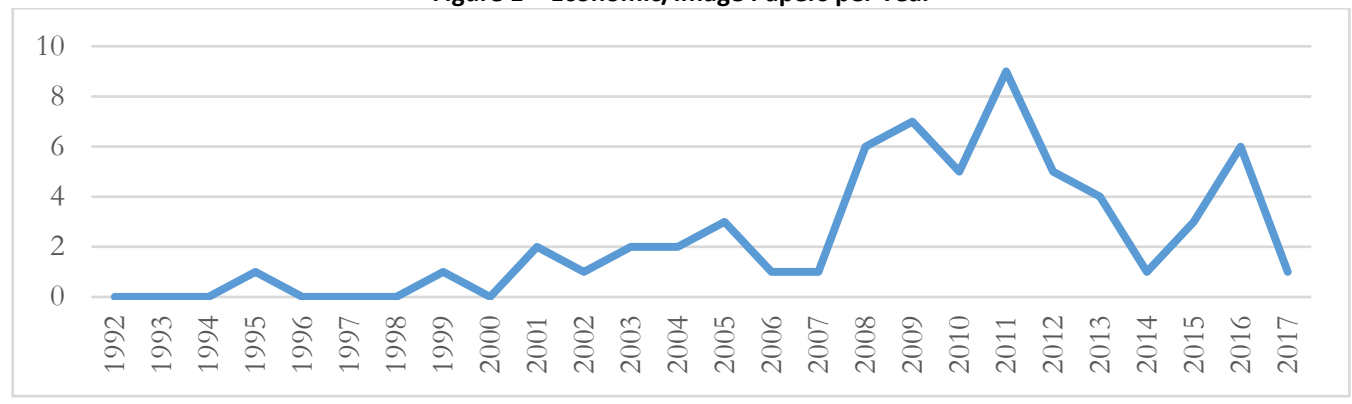

Source: Own elaboration. 
Figure 2 - Economic/Image Papers per Olympics Edition

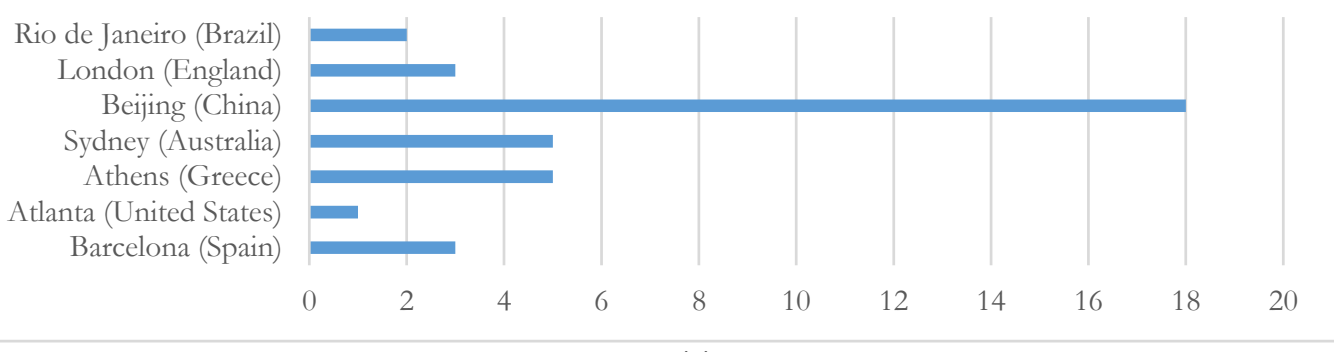

Source: Own elaboration.

Tables 5 and 6 list the main strengths/weaknesses found in the studies of each of the seven Olympic Games held in recent years.

Table 5 - Economic aspects strengths and weaknesses

\begin{tabular}{|c|c|c|}
\hline Location & Strengths & Weaknesses \\
\hline $\begin{array}{l}\text { Atlanta } \\
\text { (1996) }\end{array}$ & $\begin{array}{l}\text { Sports technological evolution; creation of } 580,000 \\
\text { new jobs for } 6 \text { years; economic impact of } 5.1 \text { billion } \\
\text { dollars over } 6 \text { years. Increase in a tourist attraction. }\end{array}$ & $\begin{array}{l}\text { Inefficient transport system; faults in the computer system; } \\
\text { safety problems; relationship problems with visitors; costs } \\
\text { exceeded forecast by } 2 \text { billion; } 15,000 \text { residents were evicted; } \\
9,500 \text { housing units were lost; shelters converted into tourist } \\
\text { accommodation. The focus was on sports buildings and not on } \\
\text { infrastructure. }\end{array}$ \\
\hline $\begin{array}{l}\text { Sydney } \\
(2000)\end{array}$ & $\begin{array}{l}\text { Remediation services; creation of new roads; new } \\
\text { railway line; telecommunications and electricity; } \\
\text { social sustainability; safety; environmental concern. }\end{array}$ & $\begin{array}{l}\text { Revenue did not exceed the cost; objectives related to } \\
\text { sustainability were not fully achieved; jobs have not been } \\
\text { sufficiently explored. }\end{array}$ \\
\hline $\begin{array}{l}\text { Athens } \\
\text { (2004) }\end{array}$ & $\begin{array}{l}\text { GDP increased by } 1.3 \% \text { per year between } 1997 \text { and } \\
2005 \text {; unemployment fell by } 1.9 \% \text { per year; the } \\
\text { opening of new airports; expansion of the city } \\
\text { subway; } 30,000 \text { new jobs; infrastructure and quality } \\
\text { of services improved. }\end{array}$ & $\begin{array}{l}\text { Loss of } 1.5 \text { billion dollars; accusations of over-invoicing and } \\
\text { misuse of public resources; low ticket sales; delays in the } \\
\text { delivery of works; traffic congestion and blocking; slow } \\
\text { progress; insecurity; high price of accommodation. The } \\
\text { tourism sector did not use the knowledge gained from the } \\
\text { Olympics. Lack of effective public management. }\end{array}$ \\
\hline $\begin{array}{l}\text { Beijing } \\
(2008)\end{array}$ & $\begin{array}{l}\text { Redevelopment process; spectacular architecture; } \\
\text { pressure for accountability; investment in } \\
\text { infrastructure; entry of many sectors into the } \\
\text { economy; construction of subway lines and } \\
\text { highways; avenues and ring roads; environmental } \\
\text { protection; construction of airports; brought more } \\
\text { business opportunities. }\end{array}$ & $\begin{array}{l}\text { Deviation of attention from social contradictions and social } \\
\text { inequality that characterize Chinese society; } 1.5 \text { million } \\
\text { people were displaced to carry out the works; most } \\
\text { expensive event as of 2008; had little security. High } \\
\text { accommodation prices; low financial return obtained; } \\
\text { unnecessary spending; lack of shopping around the Olympic } \\
\text { structure. The principal economic impacts occurred mainly in } \\
\text { the host city. }\end{array}$ \\
\hline $\begin{array}{l}\text { London } \\
\text { (2012) }\end{array}$ & $\begin{array}{l}\text { Improvement in public transportation in the } \\
\text { peripheral zone; a small number of expropriations; } \\
\text { benefits of the degraded zone in the periphery; } \\
\text { modernization and better infrastructure for these } \\
\text { areas. }\end{array}$ & $\begin{array}{l}\text { Price rises in the city; greater peripheralization of the poor, } \\
\text { excluded in the new labour market; did not have the } \\
\text { expected result for the benefit of small arts organizations and } \\
\text { for the Olympic cultural programme; Olympic cultural } \\
\text { projects and participating artists were not well aligned. }\end{array}$ \\
\hline $\begin{array}{l}\text { Rio de } \\
\text { Janeiro } \\
(2016)\end{array}$ & $\begin{array}{l}\text { Improvement in public transportation offering } \\
\text { employment recreation and leisure, opportunities. } \\
\text { The mass transit increased from 18\% to 63\%, } \\
\text { benefiting almost } 1.5 \text { million passengers per day. } \\
\text { Gains in user's satisfaction before and after the BRT. } \\
\text { They also report measures to improve the safety of } \\
\text { the bus transit system. }\end{array}$ & $\begin{array}{l}\text { Citizens that use public transport perceived the need to } \\
\text { separate the feeding bus services from mixed traffic } \\
\text { congestion. Need for improving the integration with } \\
\text { bicycles. Implementing safety measures, especially speed } \\
\text { reductions, revealing an increase of at most } 6 \text { min on BRT } \\
\text { total travel time. }\end{array}$ \\
\hline
\end{tabular}

Source: Own elaboration. 
Table 6 - Destination image strengths and weaknesses

\begin{tabular}{|c|c|c|}
\hline Location & Strengths & Weaknesses \\
\hline $\begin{array}{l}\text { Barcelona } \\
(1992)\end{array}$ & $\begin{array}{l}\text { Great investment in hotel construction; positive image } \\
\text { impact for the promotion of the country in the world; } \\
\text { improvement of the country image. }\end{array}$ & No studies were found to report negative perceptions of the image. \\
\hline $\begin{array}{l}\text { Atlanta } \\
(1996)\end{array}$ & $\begin{array}{l}\text { No studies were found to report positive perceptions of } \\
\text { the image. }\end{array}$ & $\begin{array}{l}\text { The absence of positive results for tourism; the negative image of the } \\
\text { transport, reception of the athletes and security. }\end{array}$ \\
\hline $\begin{array}{l}\text { Sydney } \\
(2000)\end{array}$ & $\begin{array}{l}\text { Classified as a favourite city for tourists and executives; } \\
\text { expenditure by foreign visitors increased by } 5 \% \text {; } \\
\text { increased publicity of the Australia country-brand; } \\
\text { Olympic Art Festivals; LiveSites! }\end{array}$ & $\begin{array}{l}\text { Festivals not so effective in promoting Australian culture; the LiveSites! } \\
\text { failed to make the correct disclosure of Australian discourse and } \\
\text { symbols. }\end{array}$ \\
\hline $\begin{array}{l}\text { Athens } \\
(2004)\end{array}$ & $\begin{array}{l}\text { No studies were found to report on the positive } \\
\text { perceptions of the image. }\end{array}$ & The decrease in the number of visitors to Athens; negative image. \\
\hline $\begin{array}{l}\text { Beijing } \\
(2008)\end{array}$ & $\begin{array}{l}\text { During the Olympics, China was seen as a less risky place } \\
\text { than in normal tourism; great concern about the image } \\
\text { that the country would pass to foreigners; visibility of } \\
\text { China in the world increased. }\end{array}$ & $\begin{array}{l}\text { China was seen as having a moderate risk as a tourist destination; } \\
\text { there were some scandals regarding the qualification of the Chinese } \\
\text { athletes and some aspects of the opening ceremony were very } \\
\text { manipulated, which generated a bad image of trying to look like } \\
\text { something that it is not. }\end{array}$ \\
\hline $\begin{array}{l}\text { London } \\
\text { (2012) }\end{array}$ & $\begin{array}{l}\text { No studies were found to report on the positive } \\
\text { perceptions of the image. }\end{array}$ & No studies were found to report negative perceptions of the image. \\
\hline $\begin{array}{l}\text { Rio de Janeiro } \\
\text { (2016) }\end{array}$ & $\begin{array}{l}\text { Hospitality associated with the Olympic Games and that } \\
\text { of Brazil positively affected attitudes toward visiting the } \\
\text { country after the Games. }\end{array}$ & $\begin{array}{l}\text { The association with the Olympic brand might bring fewer gains to } \\
\text { Brazilian tourism than expected. }\end{array}$ \\
\hline
\end{tabular}

Source: Own elaboration.

Regarding the economic aspects, even with the filters considered, articles were found that directly addressed not only economic indicators such as GDP, employment rate, unemployment rate, among others, but mainly of the investments made and expected returns for the realization of the games.

The main items that appeared in the categories of strengths were: increased employment, improved transportation, telecommunications, GDP, infrastructure, and urbanization. The weaknesses were: costs, unduly spent public resources, construction delays, poorer-than-expected results, temporary jobs and lack of investment in infrastructure (peripheralization of the poor, traffic congestion, blocking of roads and inefficient transportation).
Even in articles that deal specifically with the economic impacts of the Olympics, the image is cited as an important factor to justify the mega-event, especially related to tourism activities. However, in spite of the larger number of articles dealing with image, in some more recent stagings such as in Athens, London and Rio de Janeiro, few papers specifically analyzed these image gains for the city/host country.

It is observed that in the different stagings of the games, studies were found that indicated image gains/losses. This strengthens the view that the processes of preparation and hosting in each country are too differentiated for the results to be uniform in addition to the specificities of each country. In addition, the diverse methodological aspects in the articles also influence in their results. Table 7 shows a summary of the main studies results.

\section{Table 7 - Summary of main results}

\section{Positive results related to Economy}

- Fall in the unemployment rate and an increase of positive income through investment in infrastructure; road and airports construction, investment in public transportation, telecommunication and electronics; commercial management; benefits of the degraded zone in the periphery;

- Expenditure by foreign visitors increased;

- Great investment in hotel construction;

- Increase in tourist attraction;

- Increase the GDP.

\section{Positive results related to Image}

- Positive image impact for the promotion of the country in the world;

- Improvement of the country image;

- Tourism development;

- Increased publicity of the country-brand and country visibility;

- The decrease of risk perception toward country during the event;

- Great concern about the image that the country would pass to foreigners;

- Positive attitude toward country after the Games.

\section{Negative results related to Economy}

-Most of the job created was temporary.

-Transport system not so efficient; faults in the computer system; safety problems;

- Costs exceeded forecast, unnecessary spending, low financial return obtained, low ticket sales in some cases, price rises in the host city;

- Residents were evicted;

- Focus on investment was more on sports buildings than real infrastructure

- Accusations of over-invoicing and misuse of public resources;

- Economic impacts occurred mainly in the host city.

\section{Negative results related to Image}

- The absence of positive results for tourism;

- Negative image in the transport, reception of the athletes and security.

- Festivals not so effective in promoting culture;

- Negative image;

- Decrease in the number of visitors in some places;

- The association with the Olympic brand has brought fewer tourism gains than expected; 


\section{Conclusion}

The literature review carried out in this article allowed the proposed objective to be achieved, making a deepening of qualitative analysis related to the theme. The main economic and image implications for the host city of a sports mega-event described in the literature were analyzed.

Although there are specific studies on the subject, many are not delimited to studying the image of a tourist destination or economic impacts. Many of the studies cover several aspects of hosting an Olympic Games regarding the host destination, including the two aspects cited. However, no studies were found that directly related the impacts of the image with the economic impacts in Summer Olympic Games. Such studies would be important since even considering different studies, success cases were observed in which there were economic and image gains (Barcelona and Sydney), and the opposite (Atlanta), which may give indications of the relationship between the two aspects.

The aim of showing the two sides of the accomplishment of a sports mega-event was achieved because articles were found and analyzed that pointed to both positive and negative aspects in relation to the economic and image impacts. However, most of the studies mentioned as positive aspects of those coming from Olympic spending that provided long-term gains for the resident population. While the most cited negative aspects are related to investments that provide benefits in the short term or lack of investment in infrastructure.

Regarding economic aspects, some authors question the gains by highlighting the opportunity cost, that is, how much the destination would gain if the mega-sport investment was made in other areas. In relation to the image, there were few studies of the last Olympics. However, the positive point of literature review articles is that they indicate possible gaps in studies in the area, and this is one of them.

One of the limitations of this article is the number of databases used. Another point to be taken into consideration is that although the Olympic Games are the largest sporting event in the world, there are other events for which research can also be directed.

There is also a lack of ex-post studies on the Olympics. One of the filters of this work was to verify studies of impacts on image and economy after the accomplishment of mega-events and few works were found, taking into account that the Olympic Games are a very old mega-event, indicating that many studies may have been made about the impact forecasting of the events, and few about their effective results.

Future studies should perform ex-post research into the outcome of the Olympic Games by analyzing the economic and image impacts both separately and in relation to each other, which still has not been found in the literature.

\section{References}

Boukas, N., Ziakas, V. \& Boustras, G. (2012). Towards reviving postOlympic Athens as a cultural destination. Current Issues in Tourism, 15 (1-2), 89-105.

Broudehoux, A. M. (2011). Imagens do poder: arquiteturas do espetáculo integrado na Olimpíada de Pequim. Revista Novos Estudos, 89, 39-56.

Brown, G., Smith, A. \& Assaker, G. (2016). Revisiting the host city: An empirical examination of sports involvement, place attachment, event satisfaction and spectator intentions at the London Olympics. Tourism Management, 55, 160-172.

Casellas, A., Jutgla, E. D., \& Pallares-Barbera, M. (2010). Creación de imagen, visibilidad y turismo como estrategias de crecimiento económico de la ciudad. Finisterra, 45(90), 153-172.

Chen, N. (2012). Branding national images: The 2008 Beijing Summer Olympics, 2010 Shanghai World Expo, and 2010 Guangzhou Asian Games. Public Relations Review, 38, 731-745.

Chong, T. T. L. \& Hui, P. H. (2012). The Olympic Games and the improvement of economic well-being. Quality-of-Life Studies, 8(1), 114.

Demir, A. Z., Elioz, M., Cebi, M., Cekin, R., \& Yamak, B. (2015). A strategic approach for export: Improving country image through the Olympics. Anthropologist, 20(3), 457-461.

Deng, Q. \& Li, M. (2013), A model of event-destination image transfer. Journal of Travel Research, 53(1), $69-82$.

Garcia, B. (2001). Enhancing sport marketing through cultural and arts programme: Lesson from the Sydney 2000 Olympic arts festival. Sport Management Review, 4, 193-219.

Gibson, H. J., Qi, C. X. \& Zhang, J. J. (2008). Destination image and intent to visit China and the 2008 Beijing Olympic Games. Journal of Sport Management, 22, 427-450.

Getz, D. (1993). Festival and special events, in M. Khan, M. Olsen, \& T. Var (Eds.). VNR's Encyclopedia of Hospitality and Tourism. New York: Van Nostrand Rheinhold.

Heslop, L. A., Nadeau, J. \& O'Reilly N. (2010), China and the Olympics: views of insiders and outsiders. International Marketing Review, 27(4), $404-433$.

Hiller, H. H. (2006). Post-event outcomes and the post-modern turn: The Olympics and urban transformations. European Sport Management Quarterly, 6(4), 317-332.

Hotchkiss, J. L., Moore, R. E. \& Zobay, S. M. (2003). Impact of the 1996 Summer Olympic Games on employment and wages in Georgia. Southern Economic Journal, 69(3), 691-704.

Kaplanidou, K. (2009). Relationships among behavioural intentions, cognitive event and destination images among different geographic regions of Olympic Games spectators. Journal of Sport \& Tourism, 14(4), 249-272.

Kasimati, E. \& Dawson, P. (2008). Assessing the impact of the 2004 Olympic Games on the Greek economy: A small macro-econometric model. Economic Modelling, 26, 139-146.

Kasimati, E. (2003). Economic aspects and the Summer Olympics: A review of related research. International Journal of Tourism Research, 5(6), 433-444.

Knott, B., Fyall, A. \& Jones, I. (2015). The nation branding opportunities provided by a sport mega-event: South Africa and the 2010 FIFA World Cup. Journal of Destination Marketing \& Management, 4, 46-56.

Lai, K. (2016). Influence of event image on destination image: The case of the 2008 Beijing Olympic Games. Journal of Destination Marketing and Management, 7, 153-163.

Li, S. N. \& Blake, A. (2009). Estimating Olympic-related investment and expenditure. International Journal of Tourism Research, 11(4), 337-356.

Li, S. N., Blake, A. \& Cooper, C. (2011). Modelling the economic impact of international tourism on the Chinese economy: a CGE analysis of the Beijing 2008 Olympics. Tourism Economics, 17(2), 279-303 
Li, S., Blake, A. \& Thomas, R. (2013). Modelling the economic impact of sports events: The case of the Beijing Olympics. Economic Modelling, 30, 235-244.

Li, X. R., \& Kaplanidou, K. K. (2013). The impact of the 2008 Beijing Olympic Games on China's destination brand: A US-based examination. Journal of Hospitality \& Tourism Research, 37(2), 237-261.

Lindau, L. A, Petzhold, G., Tavares, V. B. \& Facchini, D. (2016). Megaevents and transformation of Rio de Janeiro into a mass-transit city. Research in Transportation Economics, 59, 196-203.

Malfas, M., Theodoraki, E. \& Houlihan, B. (2004). Impacts of the Olympic Games as mega-events. Municipal Engineer, 1557(M3), 209-220.

Mascarenhas, G. (2013). Londres 2012 e Rio de Janeiro 2016: conceito e realidade na produção da cidade olímpica. Revistas Continentes, 2(3), 52-72.

Melo, L. M. (2014). Experiences from World Cup 2010 in South Africa first thoughts about the implication for Brazil 2014, Retrieved August 25, 2016, from http://www.ie.ufrj.br/datacenterie/pdfs/seminarios/pesquisa/texto19 04.pdf.

Minnaert, L. (2012). An Olympic legacy for all? The non-infrastructural outcomes of the Olympic Games for socially excluded groups (Atlanta 1996 - Beijing 2008). Tourism Management, 33, 361-370.

Müller, H. \& Moesch, C. (2010). Infrastructure repercussions of mega sports events: The relevance of demarcation procedures for impact calculations, evaluated using the case of UEFA Europe 2008. Tourism Review, 65(1), 37-56.

O’Brien, D. (2005). Event business leveraging: the Sydney 2000 Olympic Games. Annals of Tourism Research, 33(1), 240-261.

Pampuch, M., De Almeida, B. S. \& Marchi Júnior, W. (2014). Os legados estruturais dos Jogos Olímpicos (1992-2008): uma revisão de literatura. Educação e Humanidades, 1(7), 1-15.

Pappalepore, I. \& Duignan, M. B. (2015). The London 2012 cultural programme: A consideration of Olympic impacts and legacies for small creative organizations in East London. Tourism Management, 54, 344-355.

Pike, S. \& C. Ryan. (2004). Destination positioning analysis through a comparison of cognitive, affective, and conative perceptions. Journal of Travel Research, 42, 333-42.

Pires, L. S., Baptista, L. F. \& Portugal, L.S. (2013). Megaeventos e o desenvolvimento urbano e regional: uma análise das especificidades e impactos provenientes dos jogos olímpicos e um panorama para a cidade do Rio de Janeiro. Anais: Encontros Nacionais da ANPUR, 15.

Proni, M. W. (2008). A reinvenção dos jogos olímpicos: um projeto de marketing. Esporte e Sociedade, 3(9), 1-35.

Proni, M. W., Araujo, L. S. \& Amorim, R. L. C. (2008). Leitura econômica dos jogos olímpicos: financiamento, organização e resultados. Rio de Janeiro: IPEA.

Qi, C. X., Gibson, H. J. \& Zhang, J. J. (2009). Perceptions of risk and travel intentions: The case of China and the Beijing Olympic Games. Journal of Sport \& Tourism, 14(1) 43-67.

Rocha, C. M. \& Fink, J. S. (2017). Attitudes toward attending the 2016 Olympic Games and visiting Brazil after the games. Tourism Management Perspectives, 22, 17-26.

Singh, N. \& Hu, C. (2008). Understanding strategic alignment for destination marketing and the 2004 Athens Olympic Games: Implications from extracted tacit knowledge. Tourism Management, 29, 929-939.

Singh, N. \& Zhou, H. (2015). Transformation of tourism in Beijing after the 2008 Summer Olympics: An analysis of the impacts in 2014. International Journal of Tourism Research, 18(4), 277-285.

Sun, Q. \& Paswan, A. (2012). Country branding through Olympic Games. Journal of Brand Management, 19(8), 641-654.

Tavares, O. (2005). Quem são os vencedores e os perdedores dos jogos olímpicos? Pensar a prática, 8(1), 69-84.

Tavares, O. (2011). Beijing 2008: os Jogos Olímpicos, a cidade e os espaços. Revista Brasileira Ciência e Esporte, 33 (2), 357-373.
Tien, C., Lo, H. C. \& Lin, H. W. (2011). The economic benefits of megaevents: A myth or a reality? A longitudinal study on the Olympic Games. Journal of Sport Management, 25, 11-23.

Yao, L., Maseri, W. \& Rasli, A. (2010), Thoughts on the real macroeconomic effects of Beijing 2008 Olympics on Chinese economy. Asian Journal of Information Technology, 9(2), 32-36

Zeng, G., Go, F. \& Kolmer, C. (2011). The impact of international TV media coverage of the Beijing Olympics 2008 on China's media image formation: a media content analysis perspective. International Journal of Sports Marketing and Sponsorship, 12 (4), $39-56$.

\section{Received: 12.08.2017}

Revisions required: 14.01 .2018

Accepted: 20.06 .2018

\section{Guest Editors:}

- J. A. Campos-Soria

- J. Diéguez-Soto

- M. A. Fernández-Gámez 